\title{
Translation as a tool in linguistic analysis
}

\author{
Palma Zlateva \\ University of Leeds
}

The English conjunction 'if' and its functional equivalents in Russian and in Bulgarian, which normally introduce conditional clauses, have a variety of other functions which may or may not be connected with their invariant meanings. The use of 'if' in combination with the negative particle 'not' and with the comparative connective 'as' to introduce syntactic elements other than conditional clauses is characterised with a whole spectrum of functional meanings, such as concession, gradation, implied suggestion, etc. These meanings and nuances of meaning, which sometimes pose real problems for the linguist, come to the surface in translations from and into English, Bulgarian and Russian. Interpretations and inter-language transformations involved in the process of translation play the role of semantic analysis and reveal functional peculiarities which are often overlooked in mono-lingual or even in contrastive grammars.

\section{Introduction}

English and Bulgarian, although not genetically related, are both analytical languages, although Bulgarian still retains some traces of synthetism. Bulgarian and Russian, on the other hand, being both Slavic languages, are close in terms of culture and expressive power, but rather different in terms of structure: unlike Bulgarian, Russian is a typical synthetic language. Often a specific synthetic structural feature, characteristic of Russian and totally absent in English, can be traced in some form or another in modern Bulgarian or one of its dialects. Thus, Bulgarian contains significant evidence of the trends and steps in the linguistic development from synthetism to analytism, providing scholars of language with valuable insights into the peculiarities and the typology of this development.

Some 15 years ago, the Group on Translation Theory at the Institute of the Bulgarian Language at the Bulgarian Academy of Sciences completed a study of the various ways of expressing conditional modality in English, Polish and Russian original texts and their Bulgarian translations. The aim of the project was to establish the prevalent [symmetrical and asymmetrical] functional equivalents of the various markers of this complex semantic category, thus providing some working guidelines for the translators from and into these languages. In trying to establish a more rigorous framework for the object of their research, the authors Alexieva and Vasseva discarded quite a few examples of the English, Russian and Bulgarian corpus which I had created for them as either border-line cases, or not belonging to the 
category at all. It is on some of these examples, to which I continued adding over the years, that I will focus my attention in this paper.

Beneath the surface of many apparently simple syntactic structures connected by means of the conjunctions if not and as if there exists a complex semantic interplay between comparison and conditionality, negated conditionality, concession and gradation. Bulgarian and Russian speakers choose different levels of explicitness in bringing to the surface of utterances those elements of their propositional structure. As a result, translators often have to spot and unveil some subtle pragmatic implicatures in the source text, and render them in a more direct way in the target language.

Larson (1984) talks of the "multiple functions of grammatical relation markers" and points out:

it is important that a translator realize that words in the grammar which have a primary meaning such as sequention, reason, and alternation, etc., may have secondary senses just like other words have secondary senses. They may have other functions than the primary usage which first comes to the mind of the mother-tongue speaker (318).

Leaving aside the somewhat arbitrary use in this statement of terms such as "meaning", "sense" and "function" and the rather general reference to "words in the grammar", the author is right: grammatical markers and connectives do cover a variety of meanings and nuances of meaning, usually deriving from their basic/core, or primary, or invariant meaning. Larson even uses as illustration of her point an example with if, namely: The door is open. If the door is open, Mary must be home. She argues that here if is not used in its:

[...] primary meaning of condition in the condition-CONSEQUENCE relation. [...] In this example, the fact that the door is open is the grounds for conclusion that Mary must be home. If is used in a secondary function. The English word which has the primary meaning of grounds would be so. The door is open, so Mary must be home. It would also be correct in English to say Since the door is open, Mary must be home. When so is used, there is no skewing between the semantic relation being encoded and the grammatical form. (Larson:318)

It could be argued, however, that here, too, if is used in its primary condition-consequence use, only we have an instance of realized condition. It is this realized condition that serves as the grounds for the [consequential] conclusion (that Mary must be home). I.e., The door is open only when Mary is home, hence If the door is open, [then] Mary must be home. However, this and similar other functions of if are analysed extensively by Alexieva (1986), so here I shall go on to discuss the functions of if in combination with the negator not. 


\section{2. if not}

The English conjunction if, which normally introduces conditional clauses, has a variety of other functions which may or may not be connected with its invariant meaning, rendered into Bulgarian by ако and in Russian bу если. There are also a number of different meanings which are characteristic of the use of if in combination with the negative particle not to introduce syntactic elements other than conditional clauses.

2.1. Most common and least loaded with various implications seems to be the use of if not to introduce some kind of [tentative] gradation of the kind "A, maybe even more [than] A", where A stands for the proposition quality or quantity, subject to gradation. There are various ways of expressing this gradation:

2.1.1. By marking explicitly the comparison. E.g.:

/1/ the only son and heir presumptive to the managerial control of his father's business, and to at least a third of his estate, if not more (TD:196) / единствен син и вероятен наследник на директорското място в предприятието на баща си, както и поне на една трета от състоянието му, ако не и повече (213);

/2/ she knew that he was as enthusiastic, if not more so, as on the night before (TD:328) / тя разбра, че възторгът му е не помальк, а може да е и по-голям, отколкото предишната вечер (356);

/3/ [...] he was in his mid-thirties, if not already in his late thirties (MD:62) / минал тридесетте, ако не и към четиридесет (58).

Minkoff gives a similar example when discussing "parallel constructions with conditional and clauses" where "the effect may sometimes be that of a sentence with homogeneous parts: Their coming was pleasant, though unexpected / It was cold though sunny / It is doubtful if not impossible (Minkoff 1958:407, underlined by me).

As can be seen from the above translations, the meaning of this type of gradation is pretty straightforward, and can be rendered into Bulgarian almost word-for-word: "А, ако не и повече от A" (A, if not even more than A), where A stands for a proposition of quality (enthusiastic, doubtful) or quantity (a third of his estate, his mid-thirties) subject to gradation or comparison. The translation of $/ 2 /$ is rather clumsy and it would have been much more adequate if the original structure were followed more closely, i.e.: същьто, дори и по-голямо желание (lit.: the same, even greater enthusiasm). 
2.1.2. By introducing with if not a word or expression with stronger meaning, rather than by overtly marking it as a degree of comparison. The semantic formula of this type of comparison would be "A, maybe even B", (where - contextually only! - B = more A). E.g.:

14/ well known, they were, for the emancipation, if not the domination of their women, and they had taken Frances [...] as a natural commander (MD:37) / те се отличаваха с това, че жените им бяха не само еманципирани, ами дори и господствуващи, и бяха приели Франсис [...] като свой естествен началник (36);

/5/ my uncle would be dead, if not buried, within a fortnight (JE:55) / чичо ми ще бъде мъртъв, може би дори погребан, до две седмици (PZ);

/6/ Frances, who was realistic, if not modest about her own achievements (MD:27) / Франсис, която може би не беше скромна, но поне имаше чувство за реалност що се отнася до собствените и постижения (31), еtc.

As we can see, in the second variant of this type of gradation, introduced by if not, the meaning of "A, maybe even $\mathrm{B}$ " is much more subtle, and as a result it is "paraphrased" in the translations in different ways. In most of them, however, the modal element of tentativeness in the gradation is rendered explicitly. Compare: [не само] реална, [ами] дори скромна оценка, може би не скромна, но поне реална оченка (lit.: not only realistic, but maybe even modest, maybe not modest, but at least realistic).

2.1.3. These two variants of gradation, i.e. the structural and the lexicosemantic one, can be combined and used simultaneously, as in:

/7/ her position, if anything, was more secure, if not more wonderful than ever it had been before (TD:447) / положението й e noсигурно, ако не и по-чудесно, отколкото някога преди (485).

The translator has chosen to interpret it by adding inappropriately to the gradation of not only more secure, but more wonderful as well, the semantic component of concession поне по-сигурно, ако не и по-чудесно (lit.: at least more secure, if not even more wonderful). Which seems quite illogical in this particular context, where we have a pretty evident case of emphatic gradation, too: по-сигурно, даже/дори по-прекрасно, i.e. more secure and even more wonderful, too.

2.2. The inadequacy of the above translational interpretation, however, is probably rooted in what we shall view as a separate type of comparison or gradation of two predications, connected by if not. This gradation is somewhat concessive in nature, and can be presented semantically as 'A, or at 
least B'. Minkoff considers the use of if to mark concession to be incorrect. Compare: "Also if is frequently, though incorrectly, used concessively: It is possible, if improbable. Mutually exclusive conditions are however in themselves concessive" (1958:329). I have come upon a similar use of if in Tom Sharpe's "Vintage Stuff":

18/ There was fagging and beating and a good deal of bullying. There were also prefects, the ritual of morning and evening chapel, cold showers, draughty dormitories and wholesome, if inedible food.

It could be argued that some uses of if in combination with ever are of a similar semantic nature, compare:

19/ Word is he won't be back for a long, long time - if ever (Jackie Collins, "Lucky"). Also:

/10/ [Once I finish a book it vanishes from my mental picture as rapidly as the road runner in the cartoon.] I don't expect to see it or think about it again for a decade or so, if ever (Larry MacMurtry "The Desert Rose").

In fact, Minkoff himself does not dispute the concessive character of the compound conjunction even if in instances such as;

$/ 11 /[.$.$] she manipulated the most unwilling and reluctant old dons$ and young undergraduates into attitudes of gallantry that Frances certainly found embarrassing, even if they didn't (MD:62) / [...] mя успяваше да накара и най-заспалите стари преподаватели, а също и студенти, да я ухажват по начин, който неминуемо притесняваше Франсис, макар да не смущаваше тях самите (58). Also:

/12/ "The point is", she was saying, "that the Romantics took all this seriously, even if we don't" (MD:65) / -Въпросът e - казваштя, че ние може и да не приемаме всичко това сериозно, но романтиците са го приемали (60).

In $/ 11 /$ we have the straightforward concessive conjunction макар да [не] as equivalent to even if, while in /12/ the same translator has rendered the concession in a different way, by може и да [не]...но, slightly shifting the structure and the position of the original clauses: We may not take all this seriously, but the Romantics did.

A concessive use of the conditional conjunction is characteristic of Bulgarian and Russian as well. Compare in:

/13/ [...] можече да прояви ако не по-добър вкус, поне повече уважение (ПВ:52) / ...могла бы проявить если не больший вкус, мо, по крайней мере, большее уважение (183) / [...] could have shown better taste, if not some small respect (53). 
And also:

14/ she had been able to evade the effects of sickness, if not the sickness itself (MD:101) / мож е да не се беше спасила от самата болест, но поне избягваше последствията й (93).

As we can see, the translators of /13/ not only preserve the semantic component of gradation, but retain the same balance between implicit and explicit in the predications. Whereas in $/ 14 /$, in order to preserve the semantic nature of the relation, the translator chooses to introduce a new predicate in the surface structure, lit. Maybe she had not been able to save herself from the sickness itself, but at least she managed to evade its consequences.

2.3. The comparison and the gradation can be combined with the concession to result in rendering yet another nuance of meaning, which can be presented as "A, although not [quite] B". E.g.:

/15/ the Cranstons were really more daring if not socially more avid of life (TD:191) / Кранстьн бяха по-смели, макар и да не ламтяха за повече светски живот (207).

The semantic component of concession is rendered explicitly in the translation by макар и да не (although not), although the parallel structure of the original predications compared is not preserved - more daring is translated as по-смели, but socially more avid of life is developed into a whole clause, namely ламтяха за светски живот (lit. craved for social life). A similar translation would have been more suitable for:

/16/ the students didn't seem to notice that they had been diverted, if not exactly deceived (MD:63) / cтудентите като че не забелязваха как тя се отклонява от въпроса, как дори ги мами с отговора си (59).

Frances was not actually deceiving the students, although she had diverted them from the adequate conclusion or answer to the problem. Hence, $к а \kappa ~ z u$ отклоняваше, макар и да не ги мамеше (lit. was diverting, although not actually deceiving them) is a more appropriate semantic interpretation than как ги отклонява, как дори ги мами (lit. diverting, even deceiving them). Another possibility to stick more closely to the meaning of the original would be to retain the Bulgarian structure suggested by the translator, but to use in place of deceive a less marked verb than мами, i.e. как тя се отклонява от въпроса, как дори ги подвежда (mislead) с отговора си. Compare also:

/17/ He had a sharp, if not brilliant tongue (TD:189) / Имаше остьр, ако не блестящ език (185). 
For this I suggest an interpretation which would require a somewhat different wording in Bulgarian, namely: oстьр, макар и не блестяш език. Translational transformations such as the ones I have just suggested seem to prove that the semantic components underlying the logic of the if not comparison and/or gradation are often contextual and implied, rather than overt and lexically explicated. This is probably the reason why their interpretations vary from context to context, and even from one translator to another.

Sometimes - although not that often - it is possible to preserve in the Bulgarian translation the same ratio between explicated and contextually implied meaning by using as an equivalent for the English if not conjunction the Bulgarian ако не и. Compare:

/18/ Accustomed to the idea, if not to the reality of resignation (JG:10) / свикнал с мисълта - ако не и с факта - да се примирява (114), and

/19/ in a spirit of definite duty, if not exactly martyrdom (MS:86) / om дух за дълг, ако не и за мъченичество (191).

It could be argued that the underlying semantics of $/ 19 /$ is closer to that of $/ 16 /$ than it is to $/ 18 /$, so a more adequate translation would be от чувство за дълг, макар и не чак с примирението на мъченик (out of a sense of duty, although not with a martyr's conciliation), or om чувство за дълг, дори донякъде с примирение (out of a sense of duty, even conciliation). But some of the informants I have referred to (in order to check back on my own interpretations and the translators' ones) do not seem to detect such difference in this particular instance.

2.4. In conclusion, there are numerous instances when the translation of structures containing the if not connective are done by parallel structures in the receiving language which do not contain any degree of semantic interpretation or interlanguage paraphrase. The boundaries between the various functions of if not are rather blurred, and that results in different interpretations of the semantic and logical connection between the two expressions which it links. This is very clearly reflected in the translations, which vary from 'ако не A, то поне B' (if not A, then at least B), to 'A, може би дори B' (A, maybe even B) and even 'A, макар и да не B' (A, although not B).

\section{3. as if}

3.1. The compound connectives as iflas though are classified in English grammars as "compound subordinators [of comparison]", along with as far as, as long as, as soon as, etc. (Cf. Quirk \& Greenbaum 1980:314). They are "normally translated into Russian by будmo (бы) or как будто (бы)" as pointed out by Borras \& Christian (1971:264), and into Bulgarian by каmo че (ли). Minkoff considers this type of use to be predicative and points out 
that "just as an adverb may stand as a predicative, so too a few adverbial clauses may be used predicatively, especially those with as if after verbs of appearance: He looks as if he could do with something to eat / It almost seems as if he didn't want to" (403). As we shall see, the element of appearance can be sufficiently marked by the conjunction $\boldsymbol{a s}$ if itself, and need not always be overtly stated by means of "verbs of appearance" like it seems or it looks.

In Bulgarian, the very comparison carried out by the compound comparative subordinator като че is marked as hypothetic or tentative, by adding to it the question particle $л и$, as in:

/20/ Ама защото вие тъй сте го научили! Каквото и да каже все в устата го зяпате, като че ли е някакъв Конфуциий (ПВ:73) / На вас меня зло берёт: смотрите ему в рот, словно перед вами сам Конфуиий (166) / You've taught him to carry on like this. He says something and you gape at him, as if he were some kind of Confucius (73);

/21/ А като види циигара, като че ли го хващуат хиляди дявол (ПВ:64) / А как увидит зажженную папиросу, сразу как будто бы тысяча чертей вселяются в него (154) / If he sees a lit cigarette, a pack of devils gets into him (70).

In $/ 21 /$, the English translator had opted for the more straightforward a pack of devils gets into him, instead of [it was/he acted] as if a pack of devils gets into him, which is perfectly plausible and far more adequate in terms of subtlety. His choice is to sacrifice the element of comparison, and transfer the element of conditionality to the predicate of the main clause, namely if he sees, rather than whenever he sees, he acts as if.

3.2. Another equivalent of as if/as though and the Russian (как) будmo (бbl) is the Bulgarian сякаш. Compare:

122/ За миг момчето изпита чувство на остро прилошаване, сякаш някой го бе ударил с юмрук в стомаха (ПВ:83) / На какуюто секунду мальчик почувствовал, что ему становится дурно, будто его ударили кулаком в солнечное сплетение (96) / For a split second the boy felt sick as though someone had hit him in the stomach with a fist (95);

/23/ Олга, която бе влязла първа, спря рязко, сякаш я бяха ударили с чукче по челото (ПВ:41) / Ольга в это время уже проходила в дверь, но, усльшиав его слова, она резко остановилась, как будто ее ударили обухом по голове (132) / Olga, having come in first, stopped short as if hit on the forehead with a hammer (47);

/24/ Същата вечер, сякаш за да доведем тая максима докрай, ние отидохме заедно в лятната бирария (ПВ:39) / Вечером этого же дня, как будто бы специиально для того, чтобы 
подтвердить начавшиеся разговоры, мы отправились в бар (130) / That evening as if to put the maxim into practice, we went to the bar-garden together (45).

In these examples the rendering of the connectives corresponds directly to the grammars' definitions. In all of them, сякаш and its equivalents as if/as though and будто, как будто and как будто бы introduce a subordinate clause of "comparison with an unreal, often imaginary and even fantastic situation” (Грамматика русского языка, vol.II, part 2, 1954:345). In fact, the Russian как будто (бы) marks the semantic component of comparison by means of $\kappa a \kappa$, and the conditionality by means of the conditional particle бbl. This, to my mind, suggests the deletion from the surface structure of a whole predicative clause, namely как было бы, если. In which case the connective как будто бы is a shortcut to an underlying logical and semantic structure, in which the comparison and the conditionality exist as separate predications. Both the comparison, and the hypothetic character of the predication in the subjunctive clause are marked overtly in English by as and the conditional if, and in Russian by как and "the modal conditionaloptative verbal particle" бы (Vinogradov 1972:528).

Сякаш is the fossilised $2^{\text {nd }} \mathrm{p}$. sg. form of the archaic verb сэкати. In fact, it was this full-notion verb that used to play the function of a subordinator in older Bulgarian texts, thus marking overtly the hypothesis as a separate predication. As seen from the following examples, taken from the archives of the Institute for the Bulgarian Language, this verb agrees in person with the concrete subject(s) expressing the speculations/hypothesis, or - in the case of the $2^{\text {nd }} \mathrm{p}$. form сякаш - with a generalised (imagined) subject. Compare:

/25/ - Ба! каза Еминъ с безпокойство; това куче сякамъ че ни познава! (1873: В.Друмев, Немастна фамилия);

/26/...те, миличките, горко са наказаха и, като чуять за мене, като ма видять, мие сякатъ, чи бама си виждать. (1870: И. Бльсков, Злочеста Кръстинка);

/27/ Да не сякат нашите читатели, че Гайдата от злорадост или от нъкакво си причудливо причастые си е зела като обичай за Търново само неприятни слухове да издава. (1863: в. “Гайда”).

Ignoring some spelling differences, which were characteristic of this period of re-establishing Bulgarian spelling standards, we cannot fail to observe that in the first three of these examples, /25/, /26/ and /27/ the forms of the full-blooded verb agree with either the person speaking - [аз] сякам $\left(1^{\text {st }}\right.$ p.sg.) in $/ 25 /$, or other agents explicitly named - миличките... ще сякать, чи in $/ 26 /$ and да не сякат нашите читатели, че in $/ 27 /-3^{\text {rd }} \mathrm{p}$. pl. respectively. Moreover, they govern a subordinate clause introduced by the conjunction че/чи (that).

As seen in the next two examples, the verbal qualities of the [generalised] $2^{\text {nd }}$ p. sg. секашь and сякаш, on the other hand, seem to have started 
to "recede", which is revealed even in deviations in its spelling. Thus it was gradually reduced to its present-day formal grammatical status of a subordinator which introduces the clause directly, without the help of a conjunction. Compare:

/28/ Като са накичи, сэкашь не е българка. И тьй я! (1868: Д. Войников, Криворазбрана ичивилизачия);

/29/ Едно конте которанте,...сякаш булка ша са жени. (1864: П.Р.Славейков, в.” Гайда").

3.3. The verb сэкати is still retained in some Bulgarian dialects in the form сакам, with the modal meaning of струва ми се (it seems to me), expressing a tentative hypothesis, just as it seems to me or it may be the case that in English. To me it was a striking fact that in some translations from Bulgarian it is precisely this meaning, no longer existing in contemporary standard Bulgarian, that has come to the surface in the English and the Russian renderings. Compare:

/30/ Моят гост въздъхна тежко и сякаш забрави за миг, че не е сам в стаята (ПВ:12) / Мой гостьтяжело вздохнул и как будто забыл на мгновение, что он не один в комнате (66) / My guest uttered a deep sigh and seemed to forget he was not alone in the room (27);

/31/ Много орли, опънали широки криле и сякаш не хвърчат, а се пльзгат, като че ги носи вятьр (ЙИ) / A great number of eagles, their wings spread wide and seeming not to fly, but to glide, as if born along by the wind (MH);

132/ Едва сега следователят сякаш се разбуди и го погледна внимателно (ПВ:92) / Следователь пристально взглянул на него. Можно было подумать, что до этого он находился в бессознательном состоянии и вдруг очнулся (108) / It was only then that the Inspector seemed to wake up and look at him attentively (106).

In all of these examples, the English translators explicate the component of [misleading] appearance of something as something different, which does involve an element of comparison.

Example /32/ illustrates another instance of changing the balance between things implied and explicitly stated in the original text in favour of "over-translation", i.e., the verbalizing in translation of subtler understatements or implicatures. The Russian translator does expand the text a lot, but seems to offer a more plausible rendering than the English one: the seem to semantic component does not refer to the waking up, as its English rendering suggests. Rather, it looked as if the Inspector was asleep until he heard something that caught his attention and made him look up at the speaker. Compare also: 
133/ Стареиът отново се появи от тьмния отвор, сякаш излизаше от гроб (ПВ:82) / Старик снова показался в темной рамке входа, можно было подумать, что он выходит из могиль (95) / The old man again emerged from the dark aperture as if rising from a grave (93);

/34/ Без очилата лицето му изглеждаше съвсем простодушно и безпомощно, сякаш иялата му сила и строгост бе скрита в златните рамки (ПВ:99) / Без очков лиць его выглядело простодушным и беспомощнным, казалось, что всю его силу и строгость скрывала эта золотая оправа (118) / With the eye-glasses off, his face appeared quite bare and helpless, as though all his severity were contained in the golden rims of his glasses, and:

135/ ...желязото, макар да беше обвито във вълнен плат, пареше ръиете му като нагорещено (ПВ:85) / Кусок железа, завернутый в шерстяную тряпку, казалось, жёг ему руки (98) / ...the piece of iron, wrapped up in woolen cloth, though it was, burned his hands as if it were red-hot (96).

Можно было подумать, что он выходит из могиль (lit.: one would think that he was rising from a grave) in /33/ is far too strong for the Bulgarian сякаш излизаше от гроб/as if rising from a grave. Example /34/ presents a rather straightforward translation - apart from the blunder of translating the subordinate clause сякаш иялата му сила и строгост бе скрита в златните рамки into Russian as казалось, что всю его силу и строгость скрывала эта золотая оправа(as though the golden rims hid), instead of as казалось, что вся его сила и строгость крылась в этой золотой оправе (as though the golden rims contained). In /35/, however, the simple comparison като нагорещено from the original is expanded in the Russian and in the English translations into whole subordinate clauses: казалось, жёг ему руки (lit. it seemed that/as if it burned his hands), and burned his hands as if it were red-hot.

The Russian translation of /34/ can be viewed as an inter-language variant of what Todorov refers to as the $2^{\text {nd }}$ type of discursive transformations, namely: "complex transformations (or reactions), characterised by the appearance [in the transformation] of a second predicate, attached to the first one, which cannot exist on its own" (Todorov 2000:105).

3.4. The explication of the "unreal comparison" (Граматика на съвременния български език, 1983:371) can be achieved in translations by means of other synonyms of seem to/кажется. Е.g.:

/36/ А пьк имаше едно суратче - бледо, като че иял живот в главата му не беше капвала капчица кръв (НХ:63) / А сам личностью - краше в гроб кладут, будто на всю жизнь в голове y него капельки крови не было (52) / And the mug he's got, all pale and white, looked like he'd never had a drop of blood in his head since the day he was born (76). 
The complex comparison look as though can be "simplified" in Bulgarian translations into a single lexical item, the verb прилича (look like), as in $137 /$. In it, a considerable economy on the level of expression is achieved without the slightest injustice to the original. Compare:

137/ The houses look as though they had just had a coat of paint (SM:275) / Къщчте приличат на току-що боядисани (95).

3.5. There is a tendency towards explicitation, combined with interpreting as almost total identity the [hypothetic] similarity, brought out by this type of comparison. It comes to the surface in some Bulgarian translations of Russian texts. E.g.:

/38/ Напомнив о себе, как бы разминку сделав перед схваткой, рыбина унялась (ВА:346) / Като напомни за себе си, все едно, че се заря за предстоящата схватка, рибата се укроти (158), and: /39/ А вот Кирилл Панкратов вернулся, поглядел и увидел будто он и не уходил на войну, может, на неделю только отлучился, съездил на ярмарку, либо еще куда: везде у него порядок и даже прибыток (КС:29) / А като се завърна Кирил Панкратов, гледа - все едно, че не е ходил на война, ей тъй, като че ли само една неделя е липсвал, откарал е нещзо на панаира или другаде, къщата му в ред, нищо не се е затрило, дори се е добавило (41).

In fact, /39/ illustrates a case of re-distribution of the implicatures of the original text in the translation. Будто он и не уходил на войну is "strengthened" to все едно, че не е ходил на война, whereas может, на неделю только отлучился is "reduced" to като че ли само една неделя е липсвал. The conversational quality and rhythm of the original has been

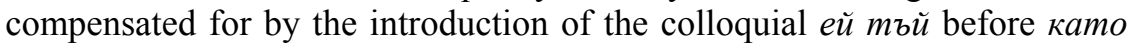
че ли. (Having coped brilliantly with getting across both the semantic and the pragmatic qualities of the original, however, the translator of this passage has fallen prey to the "false friend" неделя (week), mistranslating it into Bulgarian as the day of the week неделя (Sunday), instead of седмица (week). The use of все едно, че (the same as) in the above translation as an equivalent of будmo is a sign of yet another peculiarity of this intricate type of comparison: the closeness or similarity, established between the situation, depicted in the main clause, and the unreal, imaginary situation from the subordinate one varies in rather wide boundaries. In many cases it also points to a possible dependence or conditionality of the main predication on the subordinate one. The subtlety with which this dependence is marked gives rise to different semantic interpretations, shifting the boundary from the hypothetical to the almost identical, as was demonstrated by the above two examples. 
The almost identical relation between the two situations, predicated in the main and in the subordinate clause, however, need not necessarily be the result of over-translation. In fact, other conjunctions introducing such a comparison in Russian are the adverbials словно and точно (exactly). Compare:

/40/...околният пейзаж сега й се струваше като нов, сякаш магическа сила бе одухотворила и вляла в природата нова красота (ЕС:203) /...кружаюший пейзаж казался ей теперь каким-то обновленным, точно волшебная сила одухотворила и вдохнула в природу новую красоту (53).

In all of these instances, the English equivalent would also have been as if/as though.

3.6. Even closer to все едно, че is ровно бы (еqual to), registered in my corpus twice. Both of these examples come from Victor Astafiev's novel "Царь рыба" (The Tsar Fish). Compare:

141/ Вдруг его качнуло, ровно бы предоставляя мне возможность увидеть ещзе раз реку и землю (ВА:79) / Изведнъж то се наклони, сякаш да ми даде възможност да видя още един път реката и земята (79), and:

142/ Стерлядь была живая, изгибалась, [...] ровно бы желая улететь (293) / Чигата е още жива, гъне се, [...] сякаш ей сега ще хвръкне (294).

In both these instances the lexeme ровно is followed by the subjunctive modal verbal particle $\boldsymbol{\sigma} \boldsymbol{b}$. By explicitly marking conditionality and hypothetic character, бb seems to go against the semantics of ровно (equal to) and the meaning of [almost full] identity between the situations described in the two clauses. In fact, such a contradiction is only superficial. The close relation between comparison and conditionality, evident from the overt structural combination of as if/ as though in English and как будто бы in Russian, can be witnessed in Bulgarian as well. In it, the comparative conjunction каmo could - and still can - sometimes be used as a synonym of the subjunctive ако (if), as in the following examples from the archives of The Institute for the Bulgarian Language:

143/ Пресметнале и виделе, че имале храна, като са хранят економически (if they ate only a little), за четири цели месеци (1876: в. “Нова България");

/44/... и като зажумите и сберете въ главате си (and if you closed your eyes and brought to memory) сичките кражби оть царската хазна, ще ви са представи на очите единъ огрометь лабиринъ отъ доходи и разноски, [...] (1876: в. “Нова България”). 
In fact, contemporary colloquial English also gives us numerous examples of the expanding functions of like, to the point of gap-filler, or a short-cut to and even substitute for verbal expressions. Which - among many other things - seem to encourage situational and visual thinking at the expense of the analytical and verbal. This is not an entirely new trend in English colloquial discourse, as seems to be suggested by the following example:

145/ ...the darkies were hanging from the rafters, pop-eyed, they were so scared, but Ma was talking to the horse like he was folks and he was eating out of her hand (MМ:6) / Негрите се бяха накачили по гредите, бяха се свили там, защото бяха много изплашени, но мама говореше на коня като на човек, а той ядеше от ръката й (10).

Similar to каmo and like, the Russian бydmo, rather than introducing a subjunctive clause, can also function as a purely comparative connective again in the rather colloquial-style prose of Victor Astafiev's “Царь-рыба" (The Tsar Fish). Compare:

/46/ Зовут они себя хануками, и слово это звуком ли, боком ли подходило к ним, укладывалось, будто кирпич (like a brick) в печной кладке (ВА:252) / Те наричат себе си ханурики и дали със звука си, дали с някакъв свой ръб, тази дума много им отиваше, уйдисваше им като тухла в зидана печка (45), and:

147/ Акимка глянул: черви, будто из копилки (as if from a топеуbох), вылезают из дятла и разбежаться метят (ВА:253)/ Акимка погледнал: червеите излизали от кълвача като от спестовна касичка и се опитвали да се разпьлзят (48).

Both Russian будmo and Bulgarian като are used to introduce simple nouns as well as prepositional noun phrases, whereas English seems to favour like in front of simple nouns, but as if in front of prepositional noun phrases.

3.7. The examples I have used represent less than a third of my corpus, but I hope they have sufficiently demonstrated the points I wanted to make. To sum them up, starting backwards from the final one and coming eventually to the hypothesis I have made in the title, they are that:

1. There is a close relationship between the syntactic and semantic mechanisms of comparing different situations along the lines of similarities, either actually existing or hypothetical. The boundaries, as well as the balance between the two are often blurred, which gives rise to various possible interpretations and translational transformations. It is precisely these inter-language transformations that help reveal their complex semantics. 
2. Beneath the surface of many apparently simple syntactic structures connected by means of the connectives as if/as though, (как) будто (бы) and сякаш/като че ли there exists a complex semantic interplay between comparison and conditionality. English, Bulgarian and Russian speakers choose different levels of explicitness in bringing to the surface of utterances those elements of their propositional structure.

3. In English (and to some extent in Russian) both the comparison and the conditionality tend to be morphologically marked, whereas in Bulgarian the marking tends to be predominantly lexico-semantic.

4. Despite the various registered translational transformations, the prevalent functional equivalents of as if are как будто (бы) and словно in Russian, and сякаш/като че ли in Bulgarian, are represented respectively by $50 \%$ and by $56 \%$ of the examples in my corpus.

\section{Conclusion}

I have tried to analyse in some detail examples of various translational transformations involving structures with if not and as if and their equivalents in Bulgarian and in Russian. These are but a small part of the numerous instances when translation brings to the surface pragmatic or contextually bound components of different linguist units, thus playing the role of an applied semantic analysis. So, despite what quite a few scholars of translation (mainly former "intuitive practitioners" or literary scholars) seem to believe, linguistic approaches do have a place in translation studies. They do provide insight into the cognitive processes involved in the process of translation, just as the study of translation provides insight into the cognitive processes involved in the production of monolingual texts, oral or written.

\section{Bibliography}

Alexieva, Bistra (1986). “Прояви на асиметрия в превода на условни изречения от английски на български” (Evidence of Asymmetry in the Translation of English Conditional Sentences into Bulgarian). И. Васева, М. Иванова, Б. Алексиева. Прояви на междуезикова асиметрия при превод от чужд език на български (Evidence of Interlanguage Asymmetry in Bulgarian Translations from Foreign Languages). София: Издателство на Българската академия на науките (Sofia: Bulgarian Academy of Sciences Publishing House), 188-267.

Borras, F.M. \& R.F. Christian (1971). Russian Syntax. Aspects of Modern Russian Syntax and Vocabulary. Oxford: Oxford University Press.

Грамматика русского языка (1954). T. II. Синтаксис. (The Grammar of Russian. V.2. Syntax). Москва: Издательство Академии наук CCCP (Moscow: Russian Academy of Sciences Publishing House).

Граматика на съвременния български книжовен език (1983). T. III. Синтаксис. (The Grammar of Contemporary Standard Bulgarian. V. 3. Syntax). София: 
Издателство на Българската академия на науките (Sofia: Bulgarian Academy of Sciences Publishing House).

Larson, Mildred (1984). Meaning-Based Translation: A Guide to Cross-Language Equivalence. Lanham/New York/London: University Press of America.

Minkoff, Marko (1958). An English Grammar. Sofia: State Publishing House "Science and Art".

Quirk, Randoph \& Sidney Greenbaum (1980). A University Grammar of English. London: Longman.

Todorov, Tsvetan (2000). Цветан Тодоров. Семиотика, реторика, стилистика. (Semiotics, Rhetorics, Stylistics). София: ИК "Сема - Р.Ш.”.

Vinogradov, V.V. (1972). В. В. Виноградов. Русский язык. Грамматическое учение о слове. Издание второе. (The Russian Language. A Grammatical Study of Words. $2^{\text {nd }}$ edition). Москва: Издательство "Высшая школа" (Moscow: Higher School Publishing House).

\section{Sources of material*}

Collins, Jackie. Lucky. Pan, 1993.

Drabble, Margaret (MD). The Realms of Gold. Penguins, 1975. Средна възраст. София: Народна култура,1983. Tr. by А. Markova.

Dreiser, Theodore (TD) An American Tragedy. Bath: Cedric Chivers, 1973. Американска трагедия. София: Профиздат, 1974. Tr. by S. Florin.

Eynon, John (JE). Multiple Choice Questions in English. Texts for exercises.

Galsworthy, John (JG). To Let. Moscow: Foreign Languages Publishing House, 1961. Дава се под наем. София: Народна култура, 1969. Tr. by H. Rozeva.

Mitchell, Margaret (MM). Gone with the Wind. Dell Publishing Co., Inc., 1968. Отнесени от вихъра. София, 1945. Tr. by P. Chinkov.

Mougham, Somerset (SM). A Man of Conscience. Selected Stories. Moscow: Foreign Languages Publishing House, 1980. Тигровата кожа. София: Профиздат. 1982. Tr. by S. Florin.

Mc Murtry, Larry (LM). The Desert Rose. New York: Pocket Books, 1983.

Sharpe, Tom (TS). Vintage Stuff. Pan Books, 1983.

Spark, Muriel (MS). The Prime of Miss Jean Brodie. London: Penguin books, 1975. Разиветът на г-иа Джийн Броуди. Пловдив: Изд.“Хр.Г.Данов”, 1978. Tr. by J. Kosturkov.

Айтматов, Чингис (ЧА). Белый пароход. “Новый мир”, №.1, 1970. Избрани произведения в 2 т. Tr. by N. Hristova.

Астафьев, Виктор (BА). Царь-рыба. Москва, 1977. Цар-риба. Tr. by I. Boyadjiev

Вежинов, Павел (ПВ). Момчето с цигулката. Разкази. София, 1968. Мальчик со скрипкой. Москва: ИЛИЯ, 1963. Tr. by N. Metodieva and N. Aiba; Introduction to Modern Bulgarian Literature. New York, 1969. Tr. by G. Pavlov.

Димитрова, Блага (БД). Пътуване към себе си. София: Български писател, 1985. A Journey To Oneself. London, 1969. Tr. by R. Pridham.

Йовков, Й (ЙЙ). През чумавото. Обич. Избрани творби. София, 1982. Sofia: "Obzor" 1981. Tr. by M. Holman.

Петров, Ивайло (ИП). Преди да се родя и след това. Варна, 1971. Before I Was Born. Sofia Press, 1963. Tr. by A. Danchev.

Симонов, Константин (КС). Живые и мёртвые. Москва, 1960. Живи и мъртви. София: Изд, на ОФ, 1975. Tr. by A. Dalchev. 
Хайтов, Н (НХ). Диви разкази. Пловдив, 1970. Wild Tales. London: Peter Owen, 1979. Tr. by M. Holman.

* Where no specific page numbers have been quoted, the translations used in the analysis are mine $(\mathrm{PZ})$. 